University for Business and Technology in Kosovo

UBT Knowledge Center

UBT International Conference

2015 UBT International Conference

Nov 7th, 9:00 AM - 5:00 PM

\title{
Systems engineering application of construction permit process and positive effects on time optimization - Case study Kosova
}

\author{
Lulzim Beqiri \\ University for Business and Technology, Ibeqiri@ubt-uni.net \\ Zejnulla Rexhepi \\ University for Business and Technology, zejnulla.rexhepi@ubt-uni.net \\ Gezim Sadiku
}

Follow this and additional works at: https://knowledgecenter.ubt-uni.net/conference

Part of the Architecture Commons

\section{Recommended Citation}

Beqiri, Lulzim; Rexhepi, Zejnulla; and Sadiku, Gezim, "Systems engineering application of construction permit process and positive effects on time optimization - Case study Kosova" (2015). UBT International Conference. 66.

https://knowledgecenter.ubt-uni.net/conference/2015/all-events/66

This Event is brought to you for free and open access by the Publication and Journals at UBT Knowledge Center. It has been accepted for inclusion in UBT International Conference by an authorized administrator of UBT Knowledge Center. For more information, please contact knowledge.center@ubt-uni.net. 


\title{
Systems engineering application of construction permit process and positive effects on time optimization - Case study Kosova
}

\author{
Lulzim Beqiri ${ }^{1}$, Zejnulla Rexhepi², Gezim Sadiku ${ }^{3}$ \\ 1,2,3 UBT - Higher Education Institution; Prishtine, Republic of Kosovo \\ $\left\{\right.$ lbeqiri $^{1}$, zejnulla.rexhepi $\left.{ }^{2}\right\} @ u b t-u n i . n e t$
}

\begin{abstract}
Sy stems Engineering application to the construction industry is a permanent and continues process that bring optimization of processes that are followed with positive effects that influences positively several factor as time, cost and other related factors. Benefits through process engineering are driven forces toward process development of construction industry. This paper try to present benefits through engineering of permit process, relation of this optimization with other processes as time, cost and stakeholders benefit. The entire permit process is analyzed in Kosovo, some EU countries and as well comparison with process in Switzerland.
\end{abstract}

Keywords: Process Engineering, Permit, optimization

\section{Introduction}

Construction industry remains still far behind on systems engineering application on it processes as main factor that bring a successful output on optimization and benefits in several aspects. Analyzing application of the systems engineering in construction (Erik W. Aslaksen ,2005) it is visible that is not applied in the level that may influence focus of all stakeholders in construction process to better understanding of systems engineering application, and try ing to, as fast as possible determine factors that can have impact on systems engineering application in construction, we will try in this paper to be focused in systems engineering of a preconstruction part of construction process, in fact our focus will be from idea to the final building structure. This paper aims to present a way of reorganizing a permit process and its impact on time main factors of big interest of all stakeholders that are gathered in the triangle that connects: time, cost and quality. The model presented integrate outcomes from analy ses done to the permit process in Kosova and in Swiss. Model aim to facilitate communication between stakeholders that directly have impact on triangle factor reduction, manly at first factor that is time and then cost and quality that remains not that much influenced. Model focuses mainly in time reduction and optimization as main factor, and based on stable time factor, cost and quality will be more stable and best fulfill requirements.

\section{Systems engineering application in cons truction}

Application of systems engineering is far more applied in other industries than in construction industry that is shown in the figure below. The main steps in construction process from the idea to the final building structure involves several groups of stakeholders and in this context it is a of great interest to try to apply engineering of entire process that can be done in some of the steps of entire process but as well improvement of project management as main factor in the entire process. 


\section{Defence \& aerospace Manufacturing industry Service industry Process industry Construction industry}

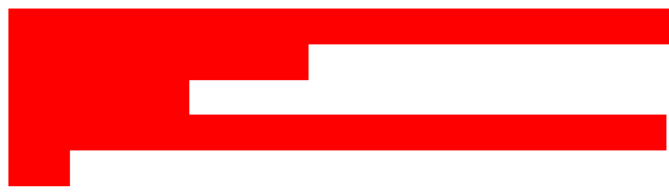

Application of Systems Engineering in Construction Industry (Erik W. Aslaksen ,2005)

Improvement of time management influences directly success of project management as will not bring additional cost and reduce quality. Each of three factors are very much related with delays that are occurred during the entire construction process and usually the pressure on project implementation makes two of three factors to have more focus by project management. The third factor will be on shoulders of the implementer as it is not possible to hold "three angles with two hand " (figure below)

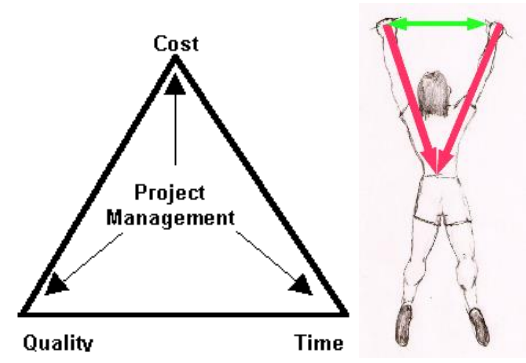

\section{Permit process analyses}

I this analy ses we did combined one case from the country that has political stability, with industrial and economic development that makes this country to be considered as developed country-Swiss, and Kosova that is country in transition, with not stable political, economic development. We did analyzed the roadmap of the entire process to get construction permit in both countries and managed to identify main steps to be improved through model provided as solution to this process. The entire process is designed and planned in favor of optimization of time, cost and quality. This is normal in developed countries as design and implementation of the systems was a log process and has a tradition. The only continues process is improvement of system, law and regulation and any other norm that regulates the process. The below scheme presents the entire process tha will be described below as well. 


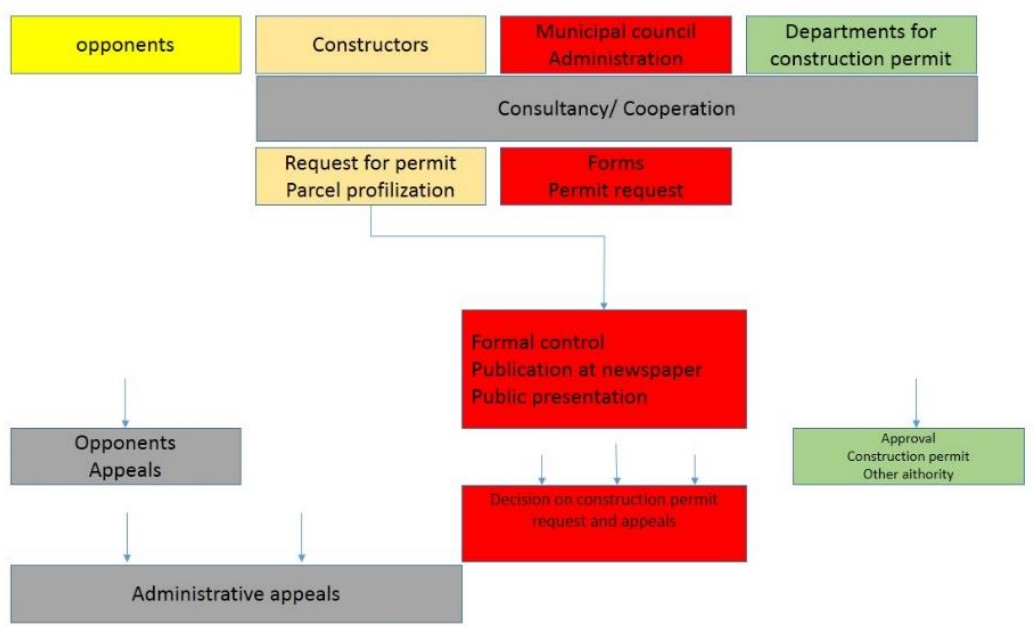

Depending on building importance such as refurbishment, small annex building, roof reconstruction, implementation of a solar and any other equipment etc., the Permit Issuing Authority (PIA) has a simple way to processed with permit of this kind of buildings. This as well has minor impact in project management and just in a few cases create possibility to have delay in any step of entire process (I case of appeal). The process steps to a construction permit are directly related to respect of laws and regulations in cantonal bases and as well in level of the municipality as end point of law and regulation implementer. Permit will be granted on time and without any delay in case when applicant respected all administrative requirement, after 30 days of appeal has been passed, building does not affect any stakeholder's interest. But those are not often cases as usually this process requires more time and stakeholders involvement. Mainly the entire permit process has some obstacle that are not technical but more related to the "power" of investor or "power" of neighbors to host the new coming construction. Normally this goes through administrative procedures that are mainly solved by respecting law and regulation by usually takes time to "satisfy" all stakeholders involved in the process. Creating time delay in the process of permit application will impact the other factors in construction process and therefore this will reflect on delay the entire process to final building structure. The process of permit becomes more complicated in some cases when you have to involve expert of relevant fields to give clarification related to impact the new construction will have in relevant field (environment, culture, etc.) . I general the entire process can be considered as process that is more dedicated to stakeholders interest but still has some improvement necessary to be applied that through engineering of the system is possible to eliminate some weakness as: law unification, regulation definition and more specification, simplification of the permit process in every new law and regulation approved by federal of cantonal government.

\section{Pe rmit Process analys es in Kosovo}

Despite international efforts to contribute on creating a legal infrastructure that will regulate every process during transition period, the construction industry, especially permit process, is still the process that mainly create delays, generate extra cost and has impact in quality as well. Construction industry, as fast growing industry in countries after conflict and in transition as well, by inertia of fast moving, sometime violate rules and regulation created to regulate construction and all steps related to construction. Another very sensitive issue is development of residential zones bey ond urban regulated areas influenced by uncontrolled migration from rural areas towards urban areas. Sometime law and regulation that are dedicate to regulate entire construction process several time are changed, adapted, or reformulated by changing several time permit process. I general this can be consider as main factor that not only has impact in permit process, but as well cannot control construction process that is main economic field that was developed after the conflict. 
The permit process is as well obscured by missing accurate data from other fields related to construction (cadaster data) that makes delay, postpone or refuse the entire permit process. As mentioned above, through the rapid growth of construction industry, companies for design and construction did not managed to build a professional structure that can initiate, lead and implement entire process, including permit process. Therefore delays are not occurred in the permit process only from PIA side but as well from the side of applicants and implementation companies. Rules and regulation could not be applied in cases with not clear definition of entire process, professional applicant and very supportive system that can facilitate communication between all factors. Above are mentioned general obstacle that have impact on process improvement but it is of interest of all stakeholders to try with reforming of entire process through systems engineering that can generate benefits through reducing delays, process classification and have impact on overall benefit. Main obstacle currently are still at PIA and general planning system that needs to accelerate based on needs of construction industry in central and local level. Information provided to applicant are another obstacle as data most of the time are not according to real situation in the field. The permit process takes more time from what is determined by the law. Because on not clarity of data, the permit process some time is repeated in total or most of the application. Changing law and regulations adapting new permit processes with new requirements not necessary is facilitating permit process. Below is presented the entire permit process in Kosova. From the figure is understandable that communication in the process of permit is localized in small groups of stakeholders that are mainly factors that are affecting permit process and creating delays. To some extend communication cannot be considered as main problem on delays to permit and construction, but when it is combine with other factors mentioned above makes process very difficult and creates delays.

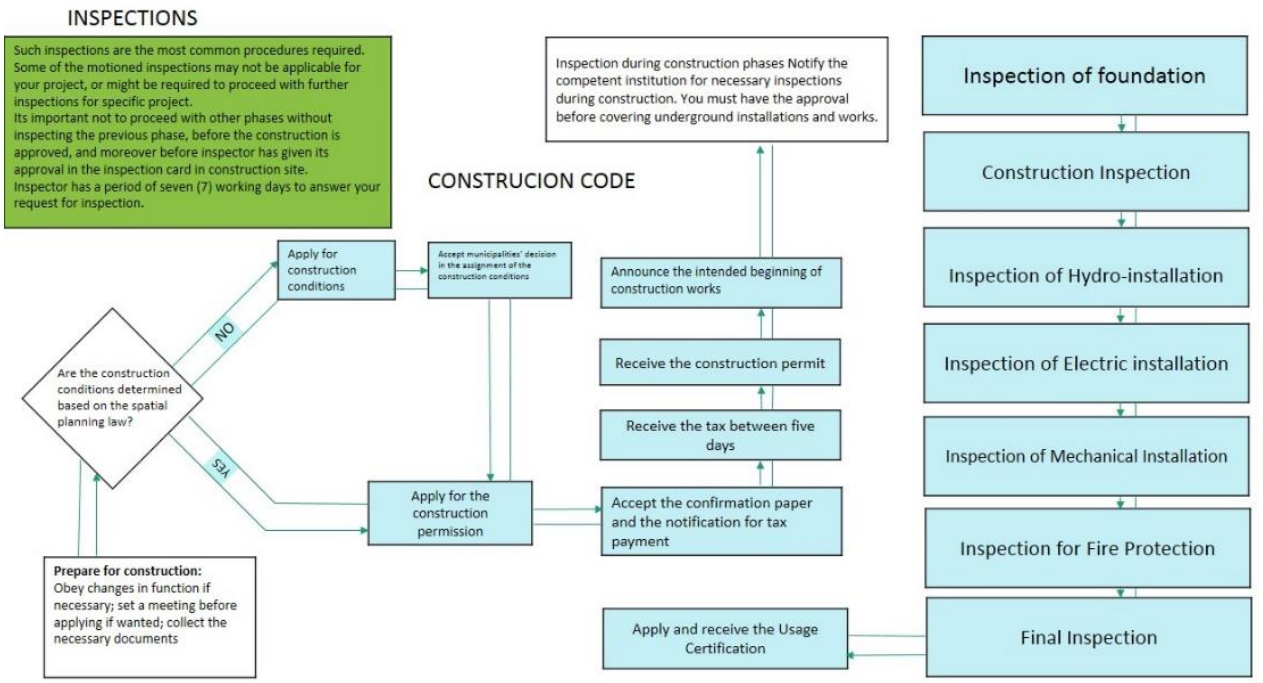

Based on analyses of permit process and possibilities to improve processes through systems engineering application it is necessary to create a model that improves communication, project management, avoid delays and improve performance of three main factors that are related directly to all stakeholders. 


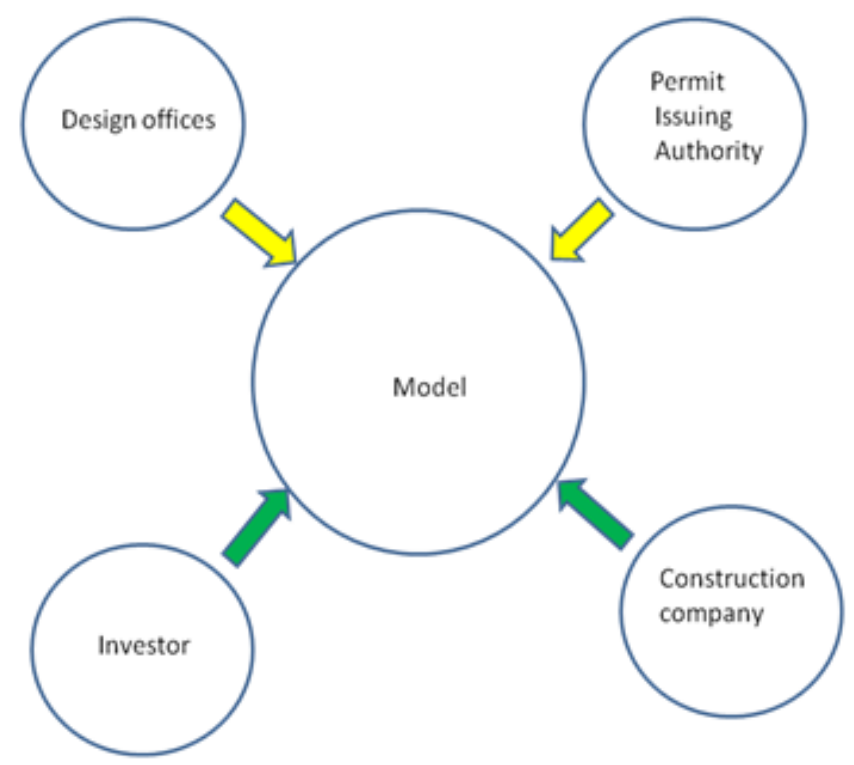

As presented above, model is designed to be an integrated point of all stakeholders, part of process from the idea to the completed building structure. The model can be considered as central point that is referring all stakeholders' interest and transforming to useful information for the rest of the stakeholders. As the process was long and with several gaps in communication, the new model manages to collect all query from the stakeholders and transform them to the useful and feedback information for the rest of the stakeholders but I the very short period of time.

Relationship listed below now are synchronized by reducing time for dealing with each stakeholder and therefore direct communication between stakeholders make possible to reduce implementation time.

1. Relation of Investors with Authorities

2. Relation of Investors with design office

3. Relation of investors with permit issuing Authority

4. Relation of investors with construction companies.

The Investor, as main stakeholder, now has new relation with all parties involved in the process, as investor will have possibility to present his idea to all of them. The model determine reducing time in this process by organizing max two meetings (depending on project complexity) with all parties involved in the process. The process from idea to the final building structure will go through following process:

- Project initiation

- $\quad$ First meeting of all stakeholders

- $\quad$ Project completing phase

- $\quad$ Second meeting- project presentation that may end up with permit of recommendation for small changes.

- $\quad$ Permit issued by PIA

- Implementation- building structure 


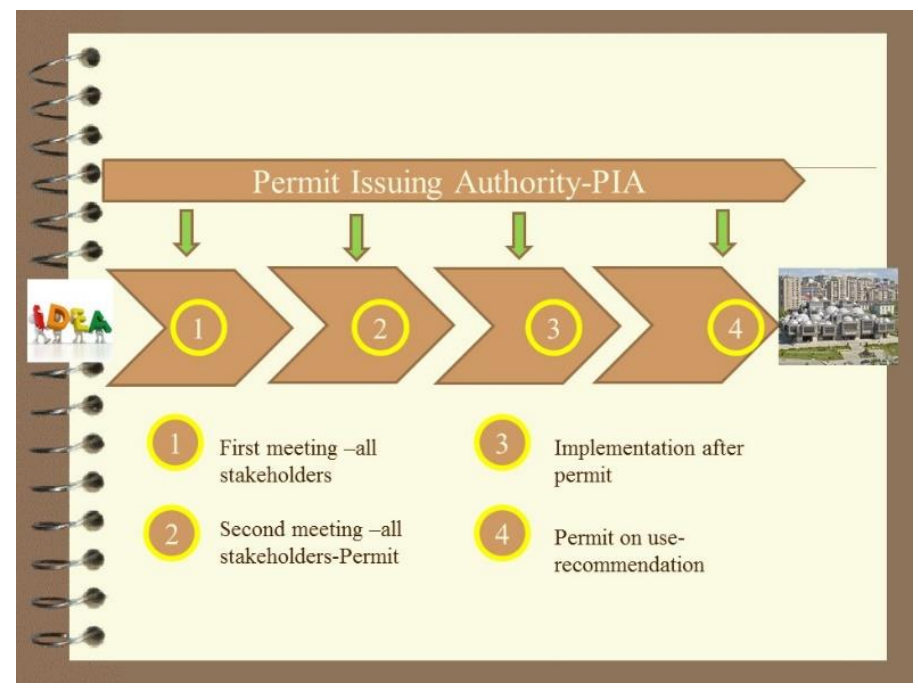

As the Permit Issuing Authority has a main role for giving project parameters, and based on those parameters issuing permit, the first information meeting (presentation meeting) will be organized at the Permit Issuing Authority initiates by investor that has idea for building that needs to be explored and adapted to a urban, technical and other parameters. Project has to be initiated by the investor as main stakeholder in entire process and the determined investor as initial phase that is idea. The process will be initiated to PIA through the request delivered phy sically or online (both methods are applicable currently) This step taken from investor allow PIA to initiate a procedure for Issuing construction permit and organize a first meeting with all stakeholders in order to give explanation and parameters requested by law and standards. In this meeting all parties that will be involved in the project will get information on idea, building format and investor's requirement that are presented by PIA.

\section{Experience Collection}

After entire process is completed, PIA will collect reports from all stakeholders involved in the process for the sake of process improvement. In the reports all stakeholders will present, share their experiences in this case and give recommendation to PIA. All recommendation will be taken in consideration to be forwarded to the local, and country level, with intension to create a global approach in the permit issuing procedures.

\section{Conclusion}

It is difficult to decide for the best model that brings positive changes and improvement in the process from idea to the final building structure through application of the systems engineering with main focus to reduce delays and through delays reduction to have direct impact on time and cost reduction. As entire process contains from three main steps that are closely related to each other as: Idea-design; permit; and construction of final building structure, the model defined from this research aims to more develop relation between three steps and facilitate process through systems engineering application that will have direct impact on entire process and influence reduction, or effective us age of time and cost that are crucial issues of entire process. Model will as well influence development of a new approach of PIA toward interested parties for building industry and through systems engineering application will be possible to initiate "state of the art" communication always being in disposal to contribute on better performance of all stakeholders. The most important issue that model brings and promote is reduction, with intention to totally eliminate, of the delay. Integrating delays management through model application influences cost, time reduction. Model has to be developed more through "state of the art" technology application that different countries are applying and be adapted to local 
requirements based on local law and standards. More important is that model influences the initiation of its application through by adapting the local procedure in order to best fit to the model and reflect positive impact of the model to the entire process.

\section{References}

1. Erik W. Aslaksen -Systems Engineering and the Construction Industry-2005

2. Carroll, A.B. and Buchholtz, A.K. (2006) Business \& Society: Ethics and Stakeholder Management (6th edn). Mason: Thomson South-Western.

3. Orndoff, C.J.W. (2005) Promising new tool for stakeholder interaction. Journal of Architectural Engineering, 11(4):139-146.

4. Bundesgesetz über die Raumplanung (Raumplanungsgesetz, RPG)1 vom 22. Juni 1979 (Stand am 1. Mai 2014) - Federal Schweiz (Swiss)

5. Raumplanungsverordnung (RPV) vom 28. Juni 2000 (Stand am 1. Januar 2015) (Swiss)

6. Erläuterungen zum Bau- und Nutzungsrecht des Kantons Aargau Version 3.1 Juni 2012 / Januar 2014 (Swiss)

7. Gesetz über Raumentwicklung und Bauwesen 1) 2) (Baugesetz, BauG) Vom 19. Januar 1993 (Stand 1. Januar 2011) Kanton Argau (Swiss)

8. Bauverordnung (BauV) Vom 25. Mai 2011 (Stand 1. Januar 2015) Kanton Argau (Swiss)

9. Gesetz über die Raumplanung und das Baurecht (Baugesetz) vom 12. Mai 2003 (Stand 1. Januar 2011) Kanton Appenzell AI/AR (Swiss)

10. Bauverordnung (BauV) Vom 25. Mai 2011 (Stand 1. Januar 2013) Kanton Appenzell AI/AR (Swiss)

11. Gesetz über die Raumplanung und das öffentliche Baurecht (Baugesetz) vom 6. Juni 1972 (Stand 1. Januar 2015) Kanton St. Gallen (Swiss)

12. http://www.mmph-rks.org/ (Kosovo)

13. Law for changing of Spatial Planning Law nr. 2003-14 - nr. 03/1-106; (Kosovo)

14. Construction law - Law nr. 04/1 - 110; (Kosovo)

15. Administrative direction $10 / 2013$ (Kosovo)

16. Administrative direction $\mathrm{nr}$. 09/2013 (Kosovo)

17. Administrative direction $\mathrm{nr}$. 08/2013 (Kosovo)

18. Administrative direction $\mathrm{nr}$. 24/2010 (Kosovo) 